Bradleya 30/2012

pages $9-12$

\title{
Charles Louis Craib: natural historian extraordinaire
}

\section{Gideon F. Smith}

Office of the Chief Director: Biosystematics Research and Biodiversity Collections, South African National Biodiversity Institute, Private Bag X101, Pretoria 0001 South Africa / Acocks Chair, Schweickerdt Herbarium, Department of Botany, University of Pretoria, Pretoria, 0002 South Africa / Centre for Functional Ecology, Departamento de Ciências da Vida, Universidade de Coimbra, 3001-455 Coimbra, Portugal (email: g.smith@sanbi.org.za).

Summary: An appreciation is provided of Charles Louis Craib's (21 ${ }^{\text {st }}$ May $1954-19^{\text {th }}$ March 2012) contributions to our knowledge of the southern African succulent and bulb floras, particularly aloes, pelargoniums and bushman candles.

Zusammenfassung: Die von Charles Louis Craib (21. May 1954 - 19. März 2012) verfassten Beiträge zu unseren Kenntnissen über die Sukkulenten- und Zwiebelpflanzenflora, insbesondere zu Arten von Aloe, Pelargonium und Buschmanns Kerzen, des südlichen Afrikas werden gewürdigt.

Charles Craib - life and times

On Monday $19^{\text {th }}$ March 2012, Charles Louis Craib (Figure 1) passed away at his home in Johannesburg, South Africa. He died of a heart attack at the young age of 57, two months short of his $58^{\text {th }}$ birthday. He is survived by his mother who is 91 years old. His funeral was held on $26^{\text {th }}$ March 2012 at 15:00 at the St Michael's Anglican Church in Bryanston, Johannesburg. Charles was one of a rare breed of holistic natural historians who had expertise in the taxonomy and ecology - including the neglected field of autecology - of large groups of South and southern Africa plants, particularly pelargoniums (Craib, 1992), succulents and bulbs (Smith, 2005).

Charles Louis Craib was born on $21^{\text {st }}$ May 1954. He completed his schooling at Pridwin Preparatory School in Melrose, Johannesburg, and St Andrew's College, Grahamstown, in the Eastern Cape (Anon., 2012). While at St Andrew's he was head of the school's Natural History Society. After matriculating, he enrolled at the University of the Witwatersrand in Johannesburg where he obtained a Baccalaureus Artium (BA) degree with majors in Law and Social Anthropology. This was followed with a BA Honours degree in Anthropology from the same

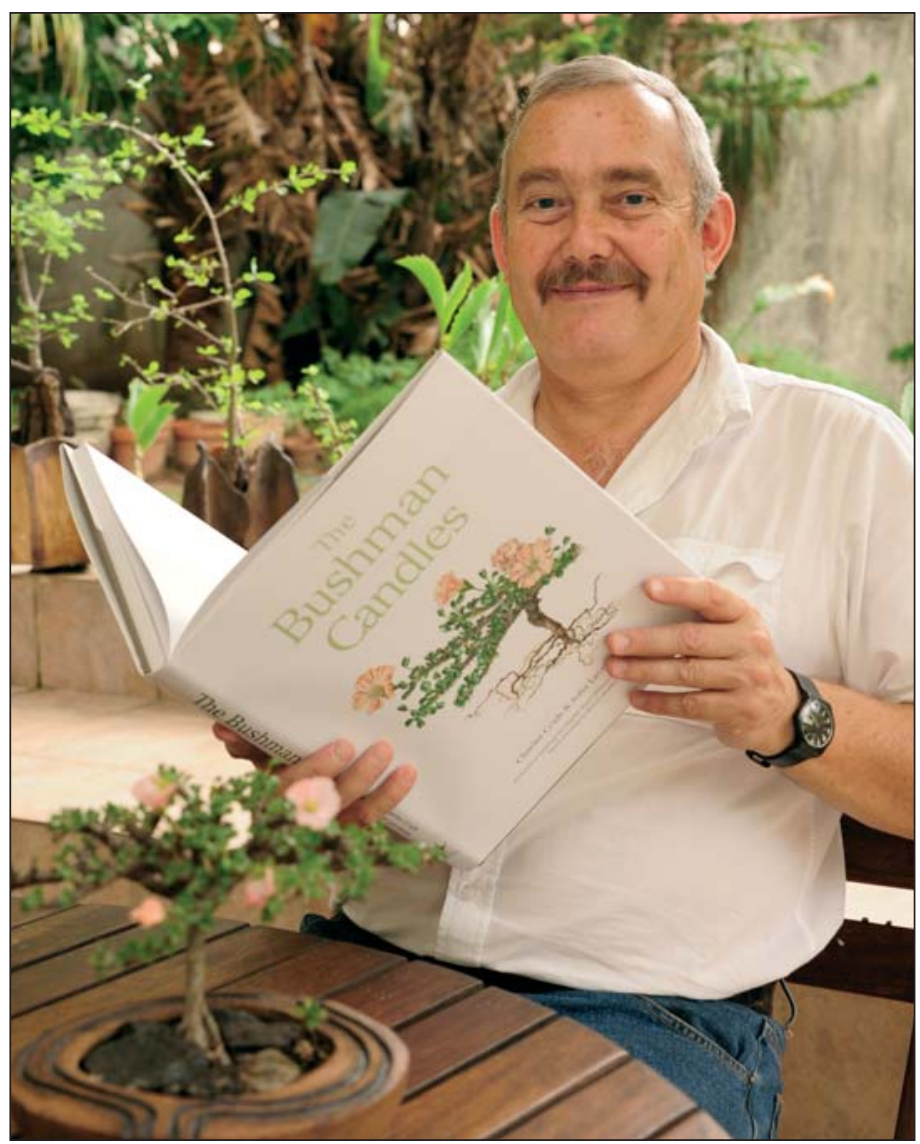

Figure 1. Charles Louis Craib. Photo: Connall Oosterbroek. 
University. He then went on to the University of Cambridge in the United Kingdom where he read for an M.Phil. degree in Social Anthropology. Following completion of that degree he returned to South Africa and between January 1979 and December 1980 completed his National Service in the Military Service Corps (Krygsdienskorps in Afrikaans) of the South African Defense Force, based at Voortrekkerhoogte, now Thaba Tshwane, $10 \mathrm{~km}$ southwest of Pretoria. After completing his 24-month conscription he was posted to the Sandton Commando Unit, where he volunteered to landscape their garden. Thereafter he briefly lectured at one of his alma mater, the University of the Witwatersrand.

From early childhood Charles spent as much time as he could, including during school holidays, in the veld, especially on the Magaliesberg north of Pretoria. Up to about 1980 his main passion was birds of prey, and the nesting habits of vultures and black eagles that occur in and around the Magaliesberg. As a young man he had no interest in the comforts of home and would simply walk into the veld and sleep there to study birds. During the late 1970's he managed to find cheap air tickets to the Canary Islands and to continental Spain and undertook several trips to parts of the Iberian Peninsula where he studied Egyptian vultures.

Shortly after completing his National Service he was employed by the Research Organization of the Chamber of Mines, where he obtained a good grounding in research methodology and in writing research reports. He spent much of his time with the Chamber of Mines conducting research for them in Namibia where he spent his spare time in the veld of this parched paradise. Not surprisingly, by 1981 Charles exchanged his love of birds of prey for the botany of Namibia: he had fallen in love with the dry desert landscapes, the hills and the plants that grew there, especially the succulents and geophytes. He was known to be able to walk and climb hills for days at a time without tiring. These emerging botanical interests lead him to eventually establish Penroc Seeds and Plants, a specialist nursery that focused on growing and propagating little known southern African plants, especially succulents and bulbs.

Charles, a perfectionist in everything he embarked on, was a friendly and gentle person who shied away from controversy and the public eye, and was happiest among his close friends, plants and books. He had a keen eye for detail and through his fieldwork a number of new species were discovered, among others a new species of grass aloe, Aloe craibii Gideon F.Sm. and a ceropegia or umbrella flower, Ceropegia craibii
J.Victor, both of which were named for him (Smith, 2003; Victor, 2001). Charles also had a keen sense for locating lost species and was involved in the rediscovery of Haemanthus avasmontanus in Namibia (Craib, 2010). The Pretoria National Herbarium (PRE) Computerised Information System (PRECIS) holds information on 18 plant specimens collected by Charles, including the types of these two species names that commemorate him.

Charles was fond of writing and widely published botanical papers in numerous national and international journals. He will indeed mostly be remembered among succulent enthusiasts for his books on several groups that would qualify as taxonomically intricate. In this regard Charles wrote three substantial works: the first, on geophytic pelargoniums (Craib, 2001) (Figure 2), as well as the second, on grass aloes of the South African veld (Figure 3), were published by Umdaus Press in Pretoria (Craib, 2005). His third book, entitled The Bushman candles, which he co-authored with succulent plant specialist John Lavranos, currently of Portugal, was on the succulent-stemmed species of Monsonia L. This group is sometimes treated as belonging to the genus Sarcocaulon

\section{Geophytic Pelargoniums}

Field and Cultivation Studies of Pelargonium section Hoarea

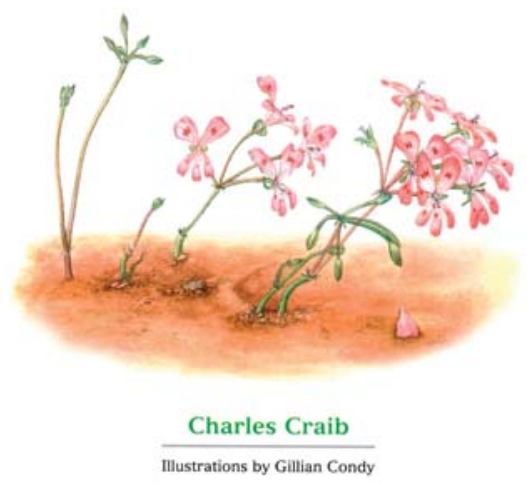

Figure 2. Charles' first book, (Craib, 2001). Cover image is Pelargonium nephrophyllum. 
(DC.) Sweet. The book on the sarcocaulons was published under the Penrock imprint - note here spelled with a 'k' at the end of the name - which gave him immense satisfaction. Earlier, the South African Pelargonium and Geranium Society, based in Northlands, Gauteng, published an A5-sized, 60-page, soft-cover booklet authored by Charles on this group (Craib, 1995).

Charles was in effect a modern-day patron of botanical art and his books were illustrated extensively by, among others, Gillian Condy of the South African National Biodiversity Institute in Pretoria. The artwork was invariably of extraordinary quality and three of the paintings completed for the grass aloe book (Aloe chortolirioides, A. craibii, A. dominella) that were exhibited at the 2004 Kirstenbosch Biennale Botanical Art Exhibition won gold medals (Kirstenbosch Biennale, 2004; Craib, 2005).

Nine days before his death, Charles donated 30 copies -25 according to the invitation to the event; five copies were made available to people connected with the exhibition - of The Bushman candles book for sale at a function held at the world renowned Everard Read Gallery in Rosebank, Johannesburg. The event took place on $10^{\text {th }}$

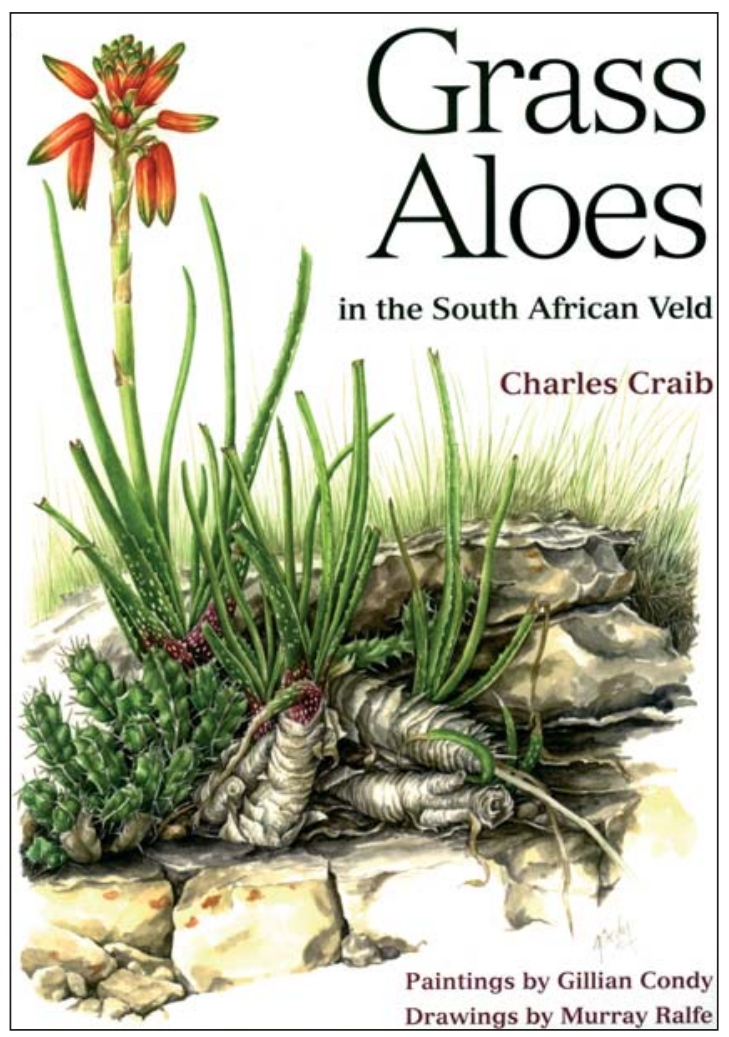

Figure 3. Charles' second book, (Craib, 2005). Cover image is Aloe fouriei.
March 2012 and all the books, which are illustrated with watercolour paintings by Ellaphie Ward-Hilhorst and Gerhard Marx, pencil drawings by Bowen Boshier and photographs by Connall Oosterbroek, were quickly sold, resulting in R27,000 raised for a project supporting conservation work on the Bokkeveld Escarpment (Gozo, 2012). A portion of income from the sale of Bowen's prints is included in the amount raised. The Bokkeveld project will be executed under the auspices of the Custodians of Rare and Endangered Wildflowers (CREW) programme of the South African National Biodiversity Institute. The exhibition held at the Everard Read Gallery was also a rare opportunity for attendees to view the original artworks included in the bushman candles book (Veldsman, 2012).

At the time of his death, Charles had already started accumulating information and images for several other substantial publication projects that he had in mind. One such book, with an as yet undetermined title, was to have dealt with habitat changes, and was intended as an in-depth study of how changes to habitats in South Africa and parts of Namibia have affected, primarily, the bulbous, caudiciform and succulent floras (see for example Craib, 2010: 67). The study was to have illustrated processes in habitats, such as the effect of grazing by livestock, and habitat degradation and destruction. As with his other books, several art forms would have featured prominently including pencil drawings, botanical art of various styles, and photography. The intention was again to have sold the bulk of this publication, if not all of it, via subscriptions in advance. This, and other projects that he envisaged, will now have to await the attention of another generation of botanists.

In the words of Victor (2001: 211): Charles was “...an enthusiastic amateur botanist whose dedication and determination is an inspiration to all." He will be sorely missed.

\section{Acknowledgements}

Ms Gillian Condy, botanical artist at the South African National Biodiversity Institute (SANBI) in Pretoria, and Messrs Arnaud Labuschagne, Connall Oosterbroek, and John Lavranos are thanked for sharing information on Charles. $\mathrm{Mr}$ Oosterbroek kindly provided the image of Charles used here. Ms Ronell Klopper of SANBI in Pretoria kindly checked PRECIS for electronic records of specimens collected by Charles.

\section{Selected publications of Charles Craib}

CRAIB, C. (1992). The natural habitat and cultivation of some southern African succulent pelargoniums. Hystrix 1(1): 1-27. 
CRAib, C. (1995). The sarcocaulons of southern Africa. Hystrix 1(3): 1-60.

CRAIB, C. (2001). Geophytic pelargoniums. Field and cultivation studies of Pelargonium section Hoarea. Umdaus Press, Hatfield, South Africa. (Figure 2.)

CRAIB, C. (2005). Grass aloes of the South African veld. Umdaus Press, Hatfield, South Africa. (Figure 3.)

Craib, C. \& Lavranos, J. (2011). The Bushman candles. Penrock Publications, Bryanston, South Africa. (Figure 1.)

\section{References}

ANON. (2012). Expert in indigenous pelargoniums dies. Saturday Star (48 hours) March 24, 2012: 11.

CRAIB, C. (2010). The rediscovery of Haemanthus avasmontanus (Amaryllidaceae) in Namibia. Herbertia 64: 67-89.

Gozo, P. (2012). Exhibition at Everard Read in support of wild flowers. uGreat News April 2012: 3, 4 .

Kirstenbosch Biennale. (2004). Kirstenbosch Biennale. Images of southern African flora. Kirstenbosch National Botanical Garden 9-26 September 2004. South African National Biodiversity Institute, Cape Town.

Sмiтh, G.F. (2003). Aloe craibii Gideon F.Sm. (Asphodelaceae: Alooideae): a new species of grass aloe from the Barberton Centre of Endemism, Mpumalanga, South Africa. Bradleya 21: 25-28.

Smith, G.F. (2005). The fascinating world of the grass aloes of South Africa. In C. CRAIB, Grass aloes of the South African veld. Pp. viii-ix. Umdaus Press, Hatfield, South Africa.

Veldsman, S. (2012). The Bushman Candles Art Exhibition. Bot. Soc. S. Afr. Pretoria Branch Newsl. June 2012: 2.

VICTOR, J.[E.] (2001). Ceropegia craibii Apocynaceae. Curt. Bot. Mag. 18: 210-213. 